\title{
PENGARUH NET INCOME TERHADAP PENETAPAN KEBIJAKAN DEVIDEN \\ PADA PT. PEGADAIAN PERSERO
}

\author{
Widiawati \\ Fakulas Ekonomi dan Bisnis Islam, UIN Sunan Gunung Djati Bandung \\ Email: widiawati@uinsgd.ac.id
}

\begin{abstract}
ABSTRAK
Perusahaan atau entitas berdasarkan tujuannya terdiri dari perusahaan yang profit oriented dan non-profit oriented (social oriented). Bagi perusahaan yang profit oriented net income atau laba merupakan tujuan utama dari kegiatan operasional usahanya. Dimana dengan laba ini perusahaan bisa bertahan hidup, tumbuh dan berkembang, bahkan dengan laba ini perusahaan mampu menyediakan kekayaan bagi para pemegang sahamyna melalui pembayaran deviden. Dimana dengan pelaporan laba dan pembagian deviden ini perusahaan bisa menunjukan performa atau kondisi finansialnya. Penulisan artikel ini bertujuan untuk mengetahui pengaruh net income terhadap penentuan kebijakan deviden pada PT. Pegadaian (Persero). Metode yang digunakan adalah deskriptif kuantitatif, yang terdiri dari analisis deskriptif, regresi linear analisis korelasi pearson product moment, koefisien determinasi dan uji signifikansi. Hasil analisis menunjukan bahwa net income berpengaruh tetapi tidak signifikan terhadap kebijakan deviden.
\end{abstract}

Kata kunci: Net Income dan deviden. 


\section{PENDAHULUAN}

Persaingan dunia usaha saat ini sangat kompetitif. Dengan demikian perusahaan harus bisa mengelola perusahaannya dengan baik, supaya bisa bersaing dan bisa mempertahankan eksistensi perusahaannya. Selain itu perusahaan yang didirikan bisa tumbuh atau berkembang, yang pada akhirnya akan menghasilkan laba atau keuntungan (profit).

Bank pada umumnya dan bank syari'ah pada khususnya merupakan suatu perusahaan atau lembaga yang tujuannya Menghasilkan laba (profit oriented). Dan terkait dengan laba perusahaan ini manajemen perusahaan harus mengambil kebijakan-kebijakan, di antaranya (1) dibagikan kepada pemegang saham dalam bentuk deviden atau (2) tidak dibagikan kepada pemegang saham dalam bentuk laba ditahan. ${ }^{1}$

Kebijakan deviden ini bisa digunakan perusahaan untuk memperlihatkan kinerja perusahaan di pasar modal, betapa tidak besar kecilnya deviden ini akan mempengaruhi harga saham. Jadi bisa mempengaruhi cara pandang investor terhadap perusahaan sehingga pada akhirnya calon investor akan memutuskan berinvestasi atau tidak terhadap perusahaan.

Hal ini sejalan dengan teori signaling bahwa signal merupakan suatu tindakan yang diambil oleh manajmen perusahaan yang memberikan petunjuk kepada investor mengenai bagaimana cara pandang investor terhadap kinerja perusahaan. ${ }^{2}$ Perusahaan mengharapkan investor akan menangkap signal tersebut, signal yang mengindikasikan

1 Muhamad, Manajemen Keuangan Syari'ah, Cetakan Kedua, (Yogyakarta: UPP STIM YKPN,2016) hlm.535

${ }^{2}$ Brigham dan Houston, Manajemen Keuangan, Cetakan Kedelapan, Diterjemahkan oleh Herman Wibowo (Jakarta: Erlangga, 2001), hlm.40 bahwa perusahaan mempunyai prospektif yang bagus di masa yang akan datang.

Bagi para investor deviden ini merupakan hasil yang diharapkan akan diperoleh sebagai akibat dari kepemilikan sahamnya selain capital gain, yaitu pendapatan yang diperoleh Ketika saham yang dimilikinya dijual dengan harga lebih tinggi dibandingkan dengan harga beli atau harga perolehannya. Deviden ini diperoleh sebagai distribusi hasil kegiatan operasi suatu perusahaan.

Komponen yang akan mempengaruhi besar kecilnya deviden yang akan dibayarkan oleh suatu perusahaan diantaranya adalah net income atau laba bersih yang dihasilkan oleh perusahaan yang bersangkutan. Net Income merupakan salah satu komponen yang merupakan hasil dari kinerja perusahaan yang sangat mempengaruhi besar kecilnya deviden. Kalangan ekonom mendefinisikan net income atau laba bersih sebagai selisih antara pendapatan atau omzet dengan biaya yang dikeluarkan oleh perusahaan dalam menjalankan kegiatan operasional perusahaannya. ${ }^{3}$ Net income atau laba merupakan keuntungan yang tersedia bagi para pemegang saham, dengan kata lain mencerminkan penambahan kekayaan bagi para pemegang saham.

Semakin besar pembayaran deviden berarti semakin besar porsi laba bersih yang diperuntukan berupa dividen kas kepada pemegang saham yang mengakibatkan semakin kecil Retention Rate (rasio laba ditahan) untuk di investasikan kembali sebaga sumber danna atau modal internal. ${ }^{4}$ Artinya kenaikan laba perusahaan akan

\footnotetext{
${ }^{3}$ Abdullah Al-Muslih dan Shalah ash-Shawi, Fiqh Ekonomi Islam, terjemahan Abu Umar Basyir (Darul Hak, Jakarta,2004) hlm. 69.

${ }^{4}$ Sitanggang. Manajemen Keuangan Perusahaan Lanjutan. (Jakarta: Mitra Wacana Media, 2013) Hal. 182
}

Volume III/ Nomor 01/ Januari 2021 
diikuti pula kenaikan pembayaran deviden pada tahun tersebut.

Pencapaian laba yang optimal sangatlah penting bagi perusahaan karena laba merupakan prestasi dari kinerja perusahaan. Dengan laba yang optimal perusahaan bisa bertahan hidup, tumbuh bahkan berkembang dan mampu menghadapi persaingan. Sebaliknya jika labanya minim atau bahkan rugi maka keterpurukan perusahaanlah yang menunggu.

Disamping itu, perusahaan yang mempunyai laba stabil seringkali dapat memperkirakan berapa besar laba dimasa yang akan datang. Perusahaan seperti ini biasanya cenderung membayarkan deviden dengan persentase yang lebih tinggi daripada perusahaan yang labanya berfluktuasi. Maka dari itu penulis tertarik untuk menganalisis pengaruh net income atau laba terhadap penentuan kebijakan deviden pada PT, Pegadaian (Persero).

\section{Metode Penelitian}

\section{Objek Penelitian}

Penelitian dilakukan pada PT. Pegadaian (Persero) dan pengambilan data diperoleh dari data sekunder berupa annual report PT. Pegadaian (Persero) melalui situs http://www.pegadaian.co.id/info-annualreport.php.

\section{Metode Penelitian}

Metode penelitian yang digunakan adalah penelitian deskriptif dengan pendekatan kuantitatif yang menggunakan data historis atau time series. "Penelitian deskriptif merupakan penelitian yang memaparkan karakteristik tertentu dalam suatu fenomena". ${ }^{5}$
Jenis dan Sumber Data

Data yang digunakan dalam penelitian ini adalah data kuantitatif. Data kuantitatif ini menyajikan penelitian berupa analisis pada data-data (numerical) yang diolah dengan metode statistika dan juga memberikan kesimpulan kuantitatif untuk menggambarkan dan menjelaskan hubungan antara variabel bebas (independent variable) dan variabel terikat (dependent variable).

Dan sumber data yang digunakan adalah data sekunder. Data sekunder dapat diperoleh dengan cara membaca, mempelajari dan memahami melalui media lain yang bersumber pada literatur dan buku-buku atau data-data dari perusahaan yang berkaitan dengan masalah yang diteliti serta media lain seperti internet. Data yang digunakan diperoleh dari Laporan Keuangan Publikasi Tahunan yang diterbitkan oleh PT. Pegadaian (Persero) melalui situs http://www. pegadaian.co.id/info-annual-report.php.

\section{Teknik Analisis Data}

Teknik analisis data merupakan cara menganalisis data penelitian, termasuk alatalat statistik yang relevan untuk digunakan dalam penelitian. Analisis data yang digunakan dalampenelitian ini adalah analisis asosiatif. Yaitu penelitian yang bertujuan untuk mengetahui hubungan dua variable atau lebih. ${ }^{6}$

Adapun tahapan analisisnya adalah analisis regresi linier sederhana, analisis korelasi pearson product moment, analisis koefisien determinasi dan uji signifikansi dengan menggunakan uji t.

${ }^{6}$ Saban Echdar. Metode Penelitian Manajemen Bisnis. (Bogor:Ghalia Indonesia, 2017) HIm 68 


\section{HASIL DAN PEMBAHASAN}

\section{Net Income (Laba Bersih)}

Net Income atau laba bersih menjadi tujuan utama bagi setiap perusahaan atau entitas yang profit eriented. Laba bersih merupakan kelebihan seluruh pendapatan atas seluruh biaya untuk seluruh periode tertentu setelah dikurangi pajak penghasilan yang disajikan dalam laporan laba rugi pada suatu perusahaan. Laba (Earnings) atau laba bersih (Net Income) mengindikasikan profitabilitas perusahaan. Laba mencerminkan pengembalian atau return kepada para pemegang ekuitas dalam bentuk saham untuk periode bersangkutan sesuai dengan lembar saham yang dimilikinya. ${ }^{7}$

Ukuran laba menggambarkan kinerja manajemen dalam menghasilkan profit. Untuk membayar bunga kreditor, dividen investor, dan pajak pemerintah. Akhir-akhir ini, telah banyak dijumpai kecendrungan untuk lebih memperhatikan ukuran laba yang terdapat pada laporan laba rugi dibandingkan dengan ukuran lainnya. Informasi laba juga dapat dipakai untuk mengestimasi kemampuan perusahaan dalam menghasilkan laba di masa yang akan datang (memprediksi atau menafsir earning power), menafsir risiko dalam berinvestasi dan lainlain. Untuk menentukan keputusan investasinya, calon investor perlu menilai perusahaan dari segi kemampuannya untuk memperoleh laba bersih sehingga diharapkan perusahaan dapat memberikan tingkat pengembalian yang tinggi. Laba bersih dapat dijadikan sebagai suatu ukuran kinerja suatu

7 Gen Norman Thomas "Analisis Komperatif Pengaruh Laba Neto dan Arus Kas Masuk Terhadap Dividen Tunai pada Perusahaan Manufaktur Barang Konsumsi di BEl". Jurnal Binus Review, Fakultas Ekonomi dan Komunikasi, Universitas BINUS. Vol.5 No. 1, Mei 2014. HIm 25. perusahaan selama periode tertentu. Laba bersih merupakan suatu ukuran seberapa besar harta yang masuk (pendapatan dan keuntungan) melebihi harta yang keluar (beban dan kerugian). Berikut data net income atau laba pada PT. Pegadaian (Persero):

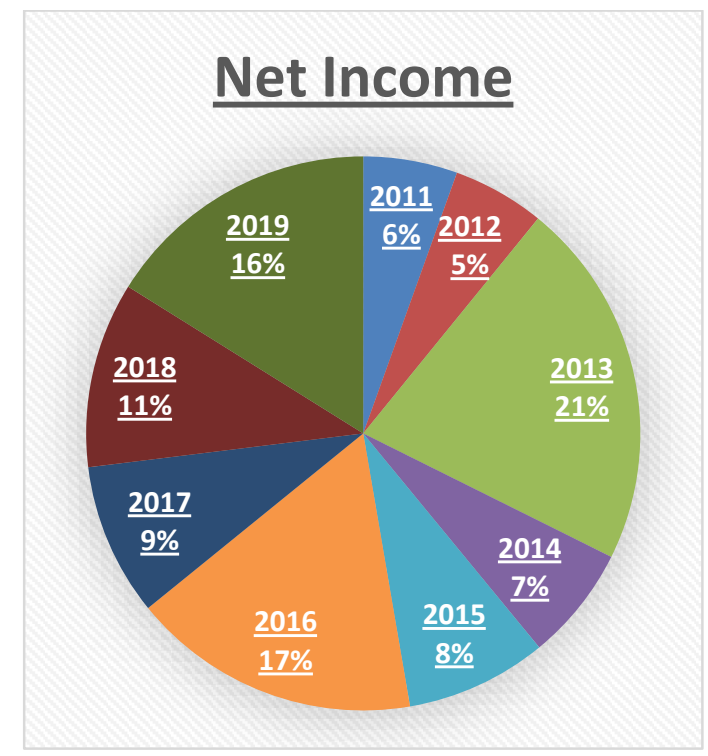

Gambar 3.1.

\section{Net Income/Laba pada PT. Pegadaian (Persero)}

Laba yang diperoleh PT. Pegadaian Persero fluktuatif untuk setiap tahunnya. Perolehan laba/net incomenya tidak stabil, tetapi cenderung akan membaik pada tahun-tahun berikutnya. Laba ini terdiri dari laba yang ditahan dan laba yang dibagikan. Laba yang ditahan merupakan sumber dana bagi pembiayaan operasional suatu perusahaan. Semakin besar pendanaan yang bersumber dari laba ditahan maka semakin kecil resiko dan biaya dana yang akan ditanggung perusahaan, sehingga kedepannya perusahaan akan memperoleh posisi keuangan atau finansial yang lebih baik lagi. Adapun laba yang dibagikan teknisnya ini dibagikan dalam bentuk deviden. 


\section{Kebijakan Deviden}

Kebijakan dividen adalah penentuan pembagian pendapatan (earning) antara penggunaan pendapatan yang dibayarkan kepada para pemegang saham sebagai dividen atau untuk digunakan di dalam perusahaan, yang berarti pendapatan tersebut harus ditahan di dalam perusahaan, dan diperuntukan sebagai tambahan dana untuk kepentingan operasional perusahaan.

Kebijakan deviden adalah dasar penentuan pembagian laba (profit/net income) antara pembayaran kepada para pemegang saham dan investasi kembali perusahaan. Laba ditahan (retained earnings) merupakan salah satu sumber dana paling penting untuk membiayai pertumbuhan perusahaan, tetapi deviden merupakan arus kas yang disisihkan untuk pemegang saham. ${ }^{8}$

Kebijakan deviden merupakan serangkaian tindakan yang harus dilakukan berkaitan dengan pembayaran deviden. Kebijakan deviden merupakan kebijakan yang memerlukan pengeluaran sangat besar, dan perusahaan terus berusaha menjaga kestabilan pembayaran deviden. Berikut deviden payment pada PT. Pegadaian Persero:

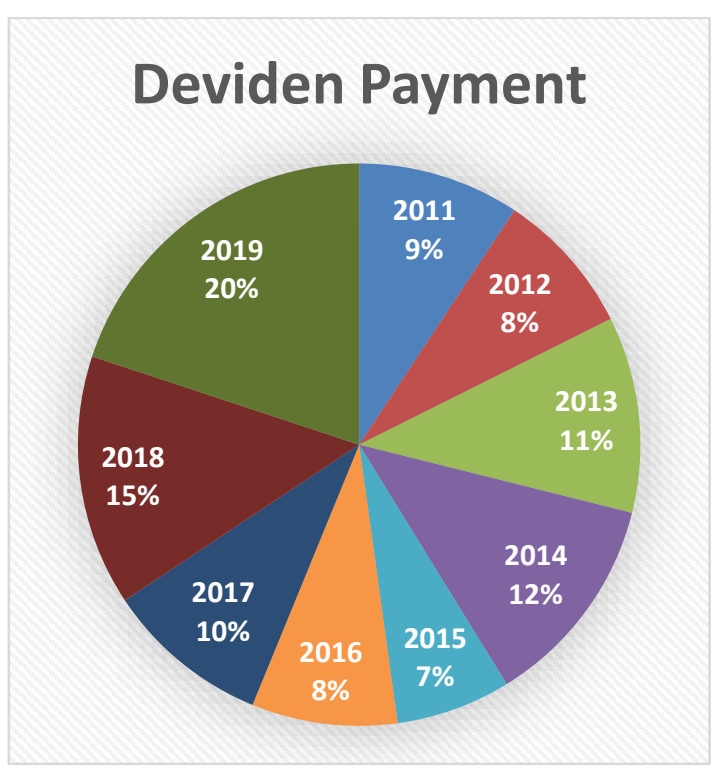

Gambar 3.1.

\section{Net Income/Laba pada PT. Pegadaian (Persero)}

Pembayaran deviden yang dilakukan PT. Pegadaian Persero berfluktuasi hanya di beberapa tahun kemudian cenderung meningkat di tahun-tahun berikutnya.

\section{Pengaruh Net Income terhadap Penetapan Kebijakan Deviden.}

Berdasarkan hasil analisis yang telah dilakukan pada variabel independen yaitu Net Income dan Kebijakan Dividen dengan menggunakan SPSS versi 18.0, maka diperoleh pembahasan sebagai berikut: 
Tabel 3.1

Regresi Linier Net Income terhadap Kebijakan Deviden

\begin{tabular}{|c|c|c|c|c|c|c|c|c|c|}
\hline \multicolumn{10}{|c|}{ Coefficients $^{a}$} \\
\hline \multirow{2}{*}{\multicolumn{2}{|c|}{ Model }} & \multicolumn{2}{|c|}{ Unstandardized Coefficients } & $\begin{array}{l}\text { Standardized } \\
\text { Coefficients }\end{array}$ & \multirow[b]{2}{*}{$\mathrm{t}$} & \multirow[b]{2}{*}{ Sig. } & \multicolumn{3}{|c|}{ Correlations } \\
\hline & & $\mathrm{B}$ & Std. Error & Beta & & & Zero-order & Partial & Part \\
\hline \multirow[t]{2}{*}{1} & (Constant) & $5.821 \mathrm{E} 11$ & $2.136 \mathrm{E} 11$ & & 2.725 & .030 & & & \\
\hline & Net_Income & .065 & .064 & .355 & 1.003 & .349 & .355 & .355 & .355 \\
\hline
\end{tabular}

a. Dependent Variable: Deviden_Payment

Nilai koefisien regresi $(\beta)$ variabel Net Income $(\mathrm{X})$ adalah sebesar 0,065 dan arah koefisien regresi adalah positif, artinya net income mempunyai hubungan yang searah dengan kebijakan dividen (Ŷ). Hasil ini menunjukkan bahwa variabel net income mempunyai pengaruh positif terhadap kebijakan dividen. Artinya semakin besar net income yang diperoleh PT. Pegadaian Persero maka akan semakin besar pula pembayaran devidennya. Jika net income meningkat sebesar 1\% maka akan diikuti kenaikan pada variable kebijakan deviden sebesar 0,065 atau sebesar $6,5 \%$.

Tabel 3.2

Korelasi Net Income terhadap Kebijakan Deviden

\begin{tabular}{|c|c|c|c|}
\hline \multicolumn{4}{|c|}{ Correlations } \\
\hline & & Net_Income & $\begin{array}{c}\text { Deviden_Payme } \\
\text { nt }\end{array}$ \\
\hline Net_Income & $\begin{array}{l}\text { Pearson Correlation } \\
\text { Sig. (2-tailed) } \\
\text { N }\end{array}$ & $\begin{array}{l}1 \\
9\end{array}$ & $\begin{array}{r}.355 \\
.349 \\
9\end{array}$ \\
\hline Deviden_Payment & $\begin{array}{l}\text { Pearson Correlation } \\
\text { Sig. (2-tailed) } \\
\text { N }\end{array}$ & $\begin{array}{r}.355 \\
.349 \\
9\end{array}$ & 1 \\
\hline
\end{tabular}

Dari hasil perhitungan di atas diperoleh koefisien korelasinya sebesar 0,365 artinya hubungan antara net income dengan kebijakan deviden termasuk ke dalam kategori hubungan yang rendah. 
Tabel 3.3

Koefisien Determinasi Pengaruh Net Incomei terhadap Kebijakan Deviden

\begin{tabular}{|c|c|c|c|c|c|c|c|c|c|}
\hline \multicolumn{10}{|c|}{ Model Summaryb } \\
\hline \multirow[b]{2}{*}{ Model } & \multirow[b]{2}{*}{$\mathrm{R}$} & \multirow[b]{2}{*}{ R Square } & \multirow{2}{*}{$\begin{array}{c}\text { Adjusted R } \\
\text { Square }\end{array}$} & \multirow{2}{*}{$\begin{array}{c}\text { Std. Error of the } \\
\text { Estimate }\end{array}$} & \multicolumn{5}{|c|}{ Change Statistics } \\
\hline & & & & & R Square Change & F Change & $\mathrm{df1}$ & $\mathrm{df2}$ & Sig. F Change \\
\hline 1 & $.355^{a}$ & .126 & .001 & 2.823E11 & .126 & 1.007 & 1 & 7 & .349 \\
\hline
\end{tabular}

a. Predictors: (Constant), Net_Income

b. Dependent Variable: Deviden_Payment

Nilai koefisien determinasi yang mempengaruhi variabel kebijakan deviden diperoleh dari perhitungan di atas sebesar hanya sebesar 12,6\%.

0,126. Dengan kata lain variabel Net Income

Tabel 3.4

Uji Signifikansi

ANOVA $^{\mathrm{b}}$

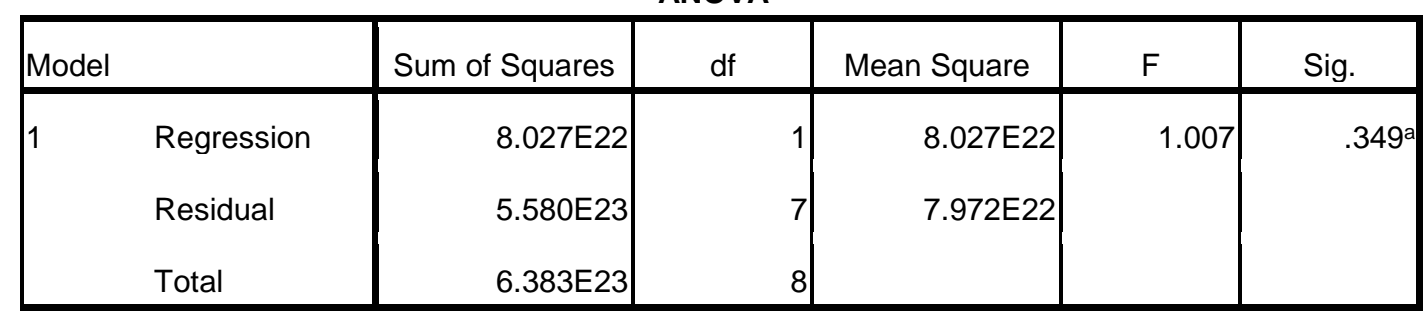

a. Predictors: (Constant), Net_Income

b. Dependent Variable: Deviden_Payment

Hasil uji signifikansi pada tabel di atas menunjukan bahwa nilai signifikansinya sebesar 0,439>0,05 artinya penaruh net income terhadap kebijakan deviden tidak signifikan. Hal ini bisa juga dilihat dari nilai korelasinya yang hanya sebesar $12,6 \%$.

\section{SIMPULAN}

Hasil penelitian membuktikan bahwa net income berpengaruh terhadap kebijakan de- viden tetapi tidak signifikan. Hal ini dilihat dengan hasil koefisien regresi sebesar 0,65 yang artinya terdapat pengaruh dan arahnya positif. Demikian pula dengan tingkat hubungan antara net income dengan kebijakan deviden tergolong kedalam kategori rendah dengan nilai korelasi 0,365. Dan net income mempengaruhi kebijakan deviden hanya sebesar12,6\% dengan nilai signifikansi sebesar $0,439>0,05$. 


\section{DAFTAR PUSTAKA}

Abdullah Al-Muslih dan Shalah ash-Shawi. 2004. Figh Ekonomi Islam, terjemahan Abu Umar Basyir. Darul Hak: Jakarta.

Asep Hermawan. 2006. Penelitian Bisnis Paradigma Kuantitatif. Grasindo, Jakarta.

Brigham dan Houston. 2011. Manajemen Keuangan, Cetakan Kedelapan, Diterjemahkan oleh Herman Wibowo. Jakarta: Erlangga.

Saban Echdar. 2017. Metode Penelitian Manajemen Bisnis. Bogor:Ghalia Indonesia.

Gen Norman Thomas “Analisis Komperatif Pengaruh Laba Neto dan Arus Kas Masuk terhadap Dividen Tunai pada Perusahaan Manufaktur Barang Konsumsi di BEI". Jurnal Binus Review, Fakultas Ekonomi dan Komunikasi, Universitas BINUS. Vol.5 No. 1, Mei 2014.

Weston, Fred, dan Eugene Brigham. Dasar-Dasar Manajemen Keuangan. Jilid 2. Edisi 7. Jakarta: Erlangga. 1992. Hal.114

Muhamad. 2016. Manajemen Keuangan Syari'ah, Cetakan Kedua, Yogyakarta: UPP STIM YKPN.

Sitanggang. 2013. Manajemen Keuangan Perusahaan Lanjutan. Jakarta: Mitra Wacana Media. 